\title{
High efficiency phosphorescent organic light-emitting devices with a new organic material as the host of the emitting layer
}

\author{
Hsin-Hung Tsai ${ }^{\mathrm{a}}$, Jiun-Haw Lee ${ }^{* a}$, and Man-Kit Leung ${ }^{\mathrm{b}}$ \\ ${ }^{a}$ Graduate Institute of Electro-Optical Engineering and Department of Electrical Engineering, \\ National Taiwan University, No. 1, Sec. 4, Roosevelt Road, Taipei, Taiwan, R.O.C.; \\ ${ }^{\mathrm{b}}$ Department of Chemistry, National Taiwan University, Taipei, Taiwan, R.O.C
}

\begin{abstract}
In this paper, we demonstrate a phosphorescent organic light emitting device (PHOLED) with low turn-on voltage by using a n-type organic material as the host of the emitting layer (EML) doped with green emitting complex, fac tris(2-phenylpyridine) iridium $\operatorname{Ir}(\mathrm{ppy})_{3}$. This material exhibits high glass transition temperature (over $\left.200^{\circ} \mathrm{C}\right)$ that may help to elongate the operation lifetime. We compare our devices to the classical 4,4'-N,N'-dicarbazole-biphenyl (CBP) based green device. Driving voltage of the CBP and the new-host based OLED is 16 and $11 \mathrm{~V}$ with the current density of $100 \mathrm{~mA} / \mathrm{cm} 2$, respectively. The lower driving voltage of the new-host based device comes from the lower HOMO value, i.e. $5.7 \mathrm{eV}$, which is nearly the same as that of NPB. The current efficiency at $10000 \mathrm{~cd} / \mathrm{m} 2$ is slightly decreased from 24 to $21 \mathrm{~cd} / \mathrm{A}$. However, the power efficiency is increased from 5 to $6 \mathrm{~lm} / \mathrm{W}$.
\end{abstract}

Keywords: OLED, phosphorescent

\section{INTRODUCTION}

High efficient phosphorescent light emitting diode (PHOLED) with carbazole based host materials has been demonstrated in recent years [1-3]. Due to the triplet state of metal-ligand charge transfer state $\left({ }^{3} \mathrm{MLCT}\right)$ of $f a c$ tris(2-phenylpyridine) iridium $\operatorname{Ir}(\mathrm{ppy})_{3}$ is between 2.5 and $3 \mathrm{eV}$, a suitable host material for efficient energy transfer is necessary. Typically, 4,4'-N,N'-dicarbazole-biphenyl (CBP), is widely used as host materials of PHOLED since the peak wavelength of fluorophores is about $400 \mathrm{~nm}$ [4]. Thus, using (Irppy)3 in CBP can lead to efficient phosphorescent emission [5].

However, for the efficient energy transfer from host material to phosphor, the bandgap of host material is mostly large. The highest occupied molecular orbital (HOMO) value of CBP is about $6.3 \mathrm{eV}$ which will result in a larger barrier for holes to inject from hole transmission layer (HTL) to emission layer (EML). Besides, Iridium based metal compounds are relatively more stable than the classical carbazole based host materials which is due to its low glass transition temperature (Tg). Thus, considering lower driving voltage and longer stability of device, the alternative for the host of PHOLED is required.

In this paper, we proposed a carbazole-free phosphorescent device by using a OXD based n-type materials which in rare and the result is far away form satisfactory [6]. As compared to the conventional CBP, this material shows a high glass transition temperature (over $200^{\circ} \mathrm{C}$ ) that may prolong the operation life time. Molecular structures of $\operatorname{Ir}(\mathrm{ppy})_{3}$ and CBP are shown in Fig. 1. In order to investigate the energy transfer of our phosphorescent system, we compared the PL (photoluminescence) of this materials and the absorption spectrum of $\operatorname{Ir}(\mathrm{ppy})_{3}$ and found the good spectrum overlap. We also optimized this PHOLED with different concentration of $\operatorname{Ir}(\mathrm{ppy})_{3}$ and compared the operation life time with carbazole based PHOLED.

*jhlee@cc.ee.ntu.edu.tw; phone 8862 2363-5251 ext. 540; fax 8862 2367-7467

Organic Light-Emitting Materials and Devices IX, edited by Zakya H. Kafafi, Paul A. Lane, Proc. of SPIE Vol. 5937, 593722, (2005) · 0277-786X/05/\$15 · doi: 10.1117/12.618897 


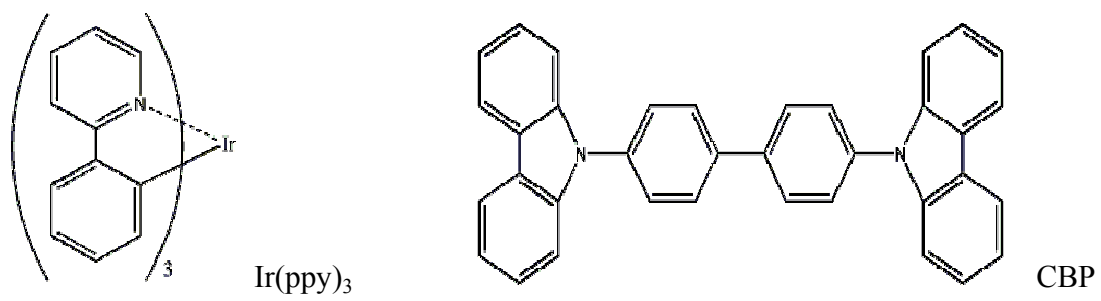

Fig. 1 Molecular structure of $\operatorname{Ir}(\mathrm{ppy})_{3}$ and CBP.

\section{EXPERIMENTS}

In all of our devices, we used ITO glass substrate of low resistivity $(10 \mathrm{Ohm} / \mathrm{sqr})$ and flat surface roughness $(\mathrm{Ra}<$ $1 \mathrm{~nm}$ ). In order to lower ITO work function and clean ITO surface, we pretreated ITO surface with $\mathrm{O}_{2}$ plasma. All the thermal evaporation of organic materials was in a batch-type chamber. The deposition rate was controlled at about 0.15 $\mathrm{nm} / \mathrm{sec}$ and the chamber pressure is under $5 \times 10^{-6}$ torr. As shown in Fig. 2, $40 \mathrm{~nm}$ N,N'-diphenyl-N,N'-bis(1-napthyl)-1,1'-biphenyl-4,4'-diamine (NPB) was used as a hole transport layer (HTL). The emitting layer (EML) consisted of this host materials with different concentration of $\operatorname{Ir}(\mathrm{ppy})_{3}$ and $\mathrm{CBP}$ in our standard device. $10 \mathrm{~nm}$ 2,9-dimethyl-4,7-diphenyl 1,10- phenanthrolin (BCP) was used as hole blocking layer and $30 \mathrm{~nm}$ tris-(8-hydroxyquinoline) aluminum acted as electron transport layer (ETL). The concentration of the $\operatorname{Ir}(\mathrm{ppy})_{3}$ is $0,3,5$, $9,15 \%$ in the new-host based devices and $9 \%$ in standard device. After organic deposition, devices were exposed in atmosphere for about 20 seconds and delivered into glove box for encapsulation. The $\mathrm{O} 2$ and $\mathrm{H} 2 \mathrm{O}$ concentrations of glove box are all below $10 \mathrm{ppm}$. Current-voltage characteristics of all devices were measured by using a Keithley 2400 source measurement unit. Brightness and emission spectrum was measured with Minolta CS1000 spectrophotometer. These instruments were connected to a personal computer and collaborated by software.

\begin{tabular}{|c|}
\hline Al $(150 \mathrm{~nm})$ \\
\hline $\operatorname{LiF}(0.1 \mathrm{~nm})$ \\
\hline Bebq2 $(30 \mathrm{~nm})$ \\
\hline BCP $(10 \mathrm{~nm})$ \\
\hline Host : x\% Ir(ppy) ${ }_{3}(30$ \\
nm $)$ \\
\hline NPB $(40 \mathrm{~nm})$ \\
\hline
\end{tabular}

\begin{tabular}{|c|}
\hline Al $(150 \mathrm{~nm})$ \\
\hline $\operatorname{LiF}(0.1 \mathrm{~nm})$ \\
\hline Bebq2 $(30 \mathrm{~nm})$ \\
\hline BCP $(10 \mathrm{~nm})$ \\
\hline CBP : 9\% Ir(ppy) ${ }_{3}(30$ \\
nm $)$ \\
\hline NPB $(40 \mathrm{~nm})$ \\
\hline
\end{tabular}

Fig. 2 Standard and compared device structures. The concentration of $\mathrm{x}$ is $0,3,5,9,15 \%$ respectively 


\section{RESULTS AND DISCUSSIONS}

Figure. 3 shows the absorption and PL spectra of $\operatorname{Ir}(\mathrm{ppy})_{3}$ and the new-host based host. Phosphorescence proceeds via either direct injection into the triplet metal ligand charge transfer state $\left({ }^{3} \mathrm{MLCT}\right)$ or via inter system crossing (ISC) from the singlet charge transfer state $\left({ }^{1} \mathrm{MLCT}\right)$. In the figure, good spectrum overlap between the host emission $(356 \mathrm{~nm})$ and the absorption of and the singlet metal-to-ligand charge-transfer state $\left({ }^{1} \mathrm{MLCT}\right)$ of $\operatorname{Ir}(\mathrm{ppy})_{3}(389.5 \mathrm{~nm})$ has been demonstrated. Thus, energy transfer from the host to $\operatorname{Ir}(\mathrm{ppy})_{3}$ seems possible.

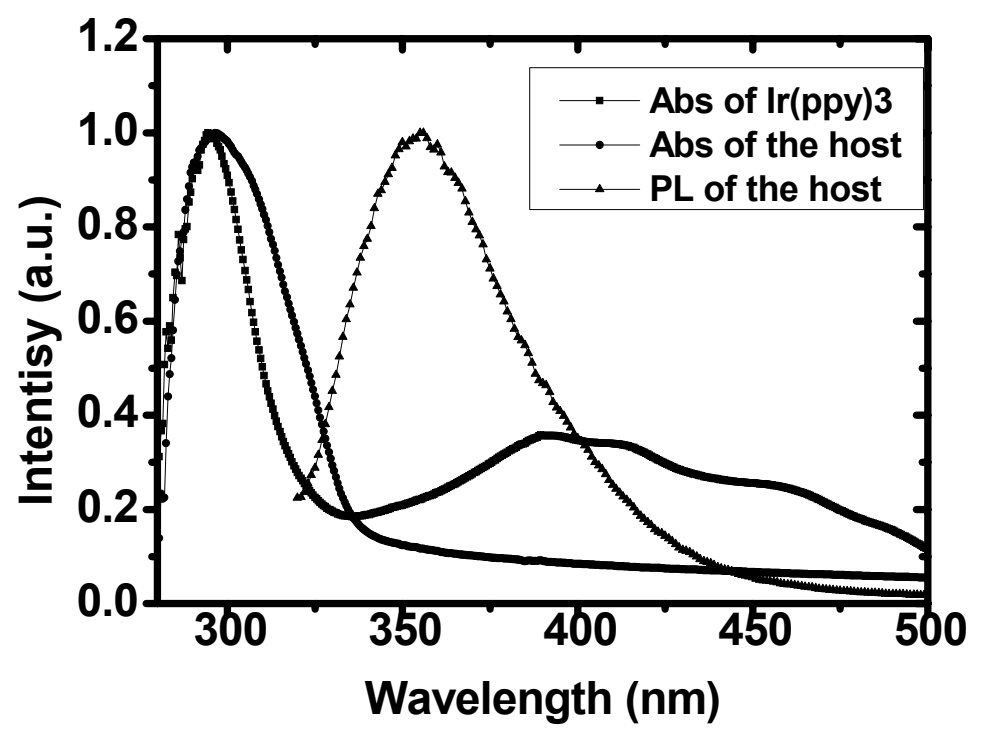

Fig. 3 The absorption spectrum of the host and $\operatorname{Ir}(\mathrm{ppy})_{3}$ and PL of the host at room temperature.

Figure 4 shows current density and voltage curves $(\mathrm{J}-\mathrm{V})$ characteristics of host: $\mathrm{x} \% \operatorname{Ir}(\mathrm{ppy})_{3}$ and CBP : $9 \% \operatorname{Ir}(\mathrm{ppy})_{3}$ devices. We can see that under the current density of $100 \mathrm{~mA} / \mathrm{cm} 2$, the driving voltage of the new-host and CBP based OLED is 11 and $16 \mathrm{~V}$. Since the HOMO value of CBP is $6.3 \mathrm{eV}$ which is lower than HTL material, NPB, the higher driving voltage is expected. However, since the HOMO value of our EML host is comparable to NPB, it results the lower driving voltage in these devices. With different dopant concentration, we can see that the driving voltage increases then decreases in the devices based on the new host. Here, we propose a model to explain this phenomenon. Since the host is a n-type material and $\operatorname{Ir}(\mathrm{ppy}) 3$ is a kind of p-type molecule, holes (electrons) hop among the $\operatorname{Ir}(\mathrm{ppy}) 3$ (the host) molecules in the EML. When the doping concentration is low, the distance between the $\operatorname{Ir}($ ppy) 3 molecules are large and it acts like a hole trap. Such a hole trap impedes further hole injection and the voltage increases. However, when the doping concentration increases, the hole mobility increases since the distance between the $\operatorname{Ir}(\mathrm{ppy}) 3$ molecules decreases. Such an amipolar transport characteristics effectively decreases the driving voltage.

Figure 5 shows the luminance-current density characteristics of the new-host based device with different concentration of $\operatorname{Ir}(\mathrm{ppy})_{3}$ and $\operatorname{Ir}(\mathrm{ppy})_{3}: \mathrm{CBP}$ device. Compared the new-host: $\mathrm{x} \% \operatorname{Ir}(\mathrm{ppy})_{3}$ with different concentration under the same voltage, $15 \% \operatorname{Ir}(\text { ppy })_{3}$ has the highest luminance of $15000 \mathrm{~cd} / \mathrm{m}^{2}$ However, CBP: $9 \% \operatorname{Ir}(\mathrm{ppy})_{3}$ has the highest performance of luminance under the same current density. It seems that the better luminance can be attributed to more effective hole trapping on $\operatorname{Ir}(\mathrm{ppy})_{3}$. 


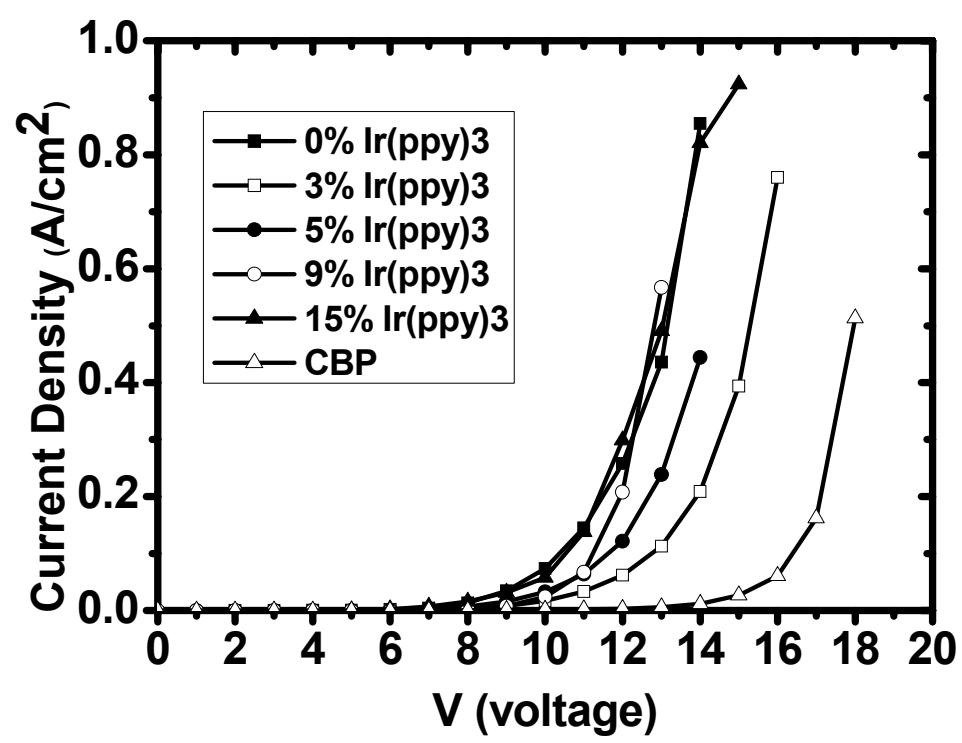

Fig. $4 \mathrm{~J}-\mathrm{V}$ characteristics for host: $\mathrm{x} \%$ and CBP : $9 \%$ devices. The concentration of $\mathrm{x}$ is $0,3,5,9,15 \%$ respectively.

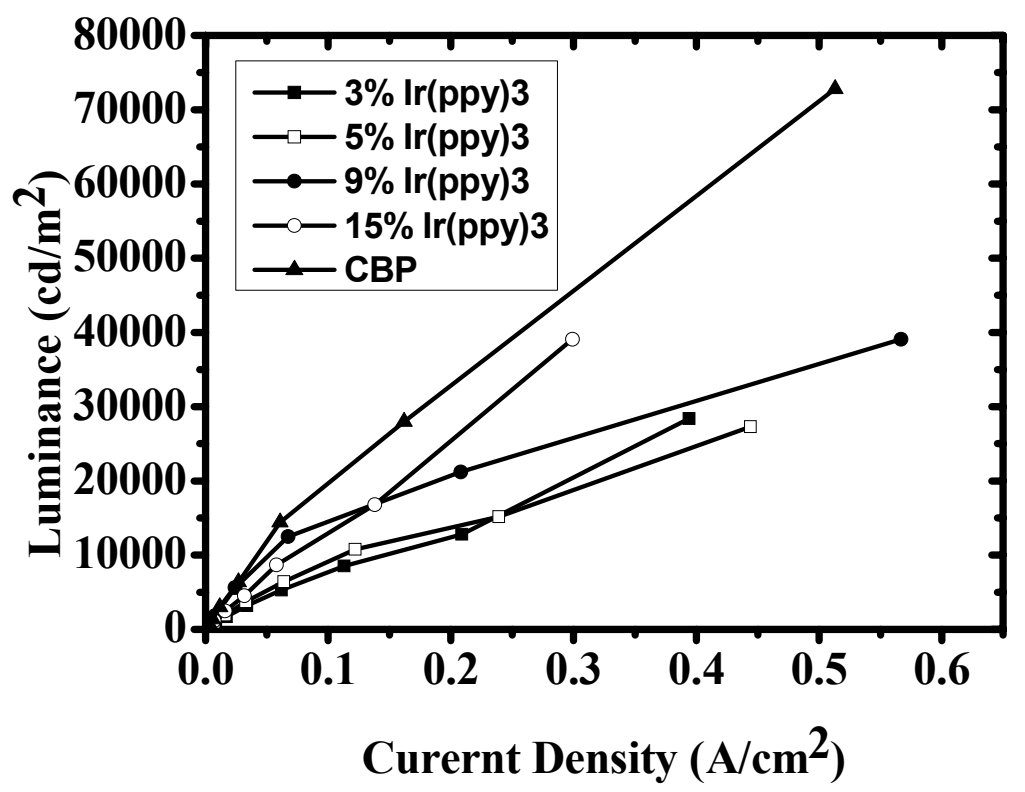

Fig. 5 The luminance versus current density curves of $\operatorname{Ir}(\mathrm{ppy})_{3}:$ the new-host and $\operatorname{Ir}(\mathrm{ppy})_{3}: \mathrm{CBP}$ device.

Figure 6 shows the result of current efficiency versus current density curves. For the new-host: $\mathrm{x} \% \operatorname{Ir}(\mathrm{ppy})_{3}$ devices, $9 \% \operatorname{Ir}(\mathrm{ppy})_{3}$ has the highest current efficiency of $21 \mathrm{~cd} / \mathrm{A}$ under the luminance of $10000 \mathrm{~cd} / \mathrm{m}^{2}$. Although the luminance of the new-host : $15 \% \operatorname{Ir}(\mathrm{ppy})_{3}$ is higher than $9 \% \operatorname{Ir}(\mathrm{ppy})_{3}$, the higher current density of $15 \% \operatorname{Ir}(\mathrm{ppy}) 3$ caused by more efficient injection of holes through $\operatorname{Ir}(\text { ppy })_{3}$ has the lower current efficiency. Comparing the optimized the new-host based PHOLED with CBP based device, the current efficiency of CBP : $9 \% \operatorname{Ir}(\mathrm{ppy})_{3}$ is about $24 \mathrm{~cd} / \mathrm{A}$ which is higher 
than the new-host : $9 \% \operatorname{Ir}(\text { ppy })_{3}$.

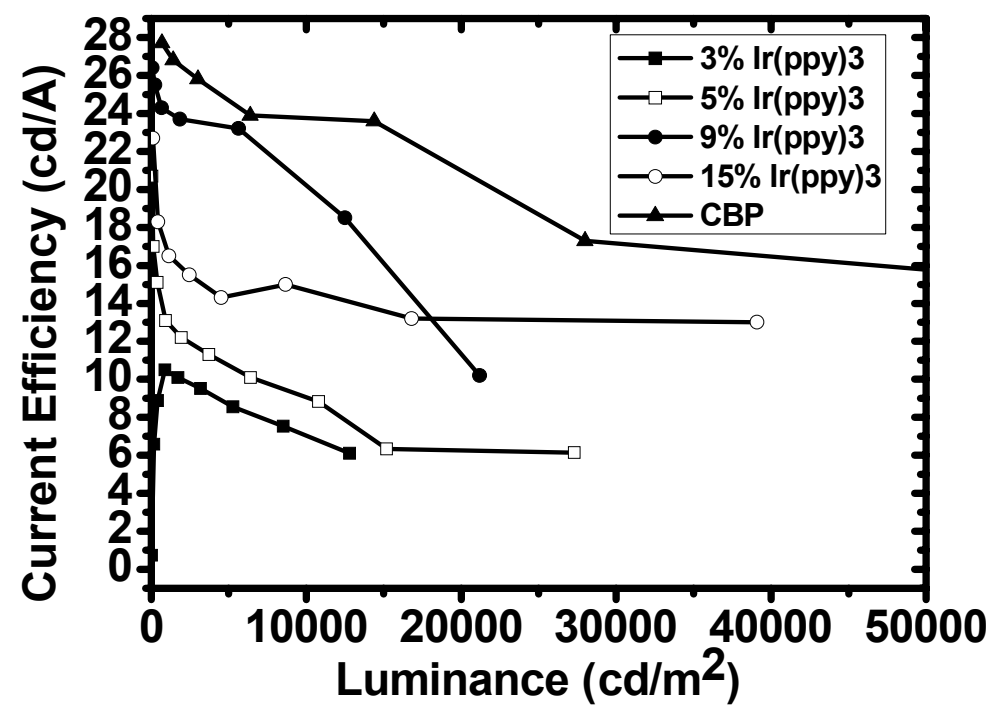

Fig. 6 Current efficiency versus luminance curves .

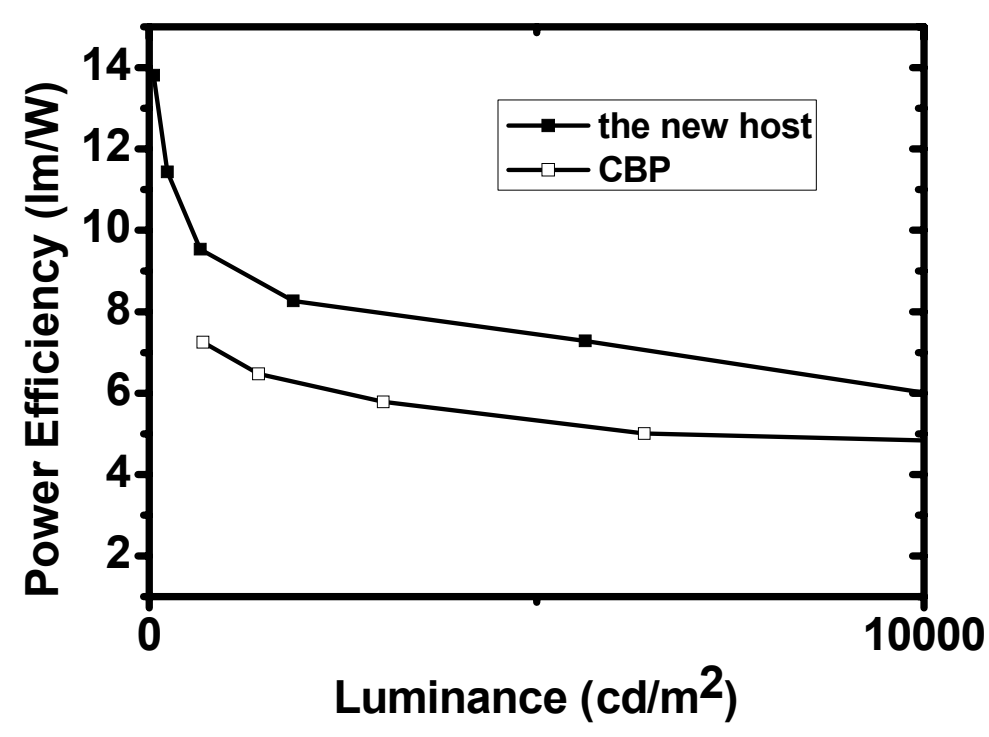

Fig. 7 Power efficiency versus luminance curves .

Figure 7 shows the power efficiency versus luminance characteristics. Due to the triplet-triplet annihilation at the interface between HBL and EML with increasing luminance, both the new-host and CBP based devices exhibit a gradual decrease in quantum efficiency. Besides, the higher power efficiency of the new-host based device can be explained in 
terms of the lower driving voltage of the new-host based device.

\section{SUMMARY}

In conclusion, high stability and high efficiency carbazole-free phosphorescent OLED has been demonstrated, utilizing a multilayer architecture with BCP as the hole blocking layer. Driving voltage of the traditional CBP based device and the new-host based OLED is 16 and $11 \mathrm{~V}$ with the current density of $100 \mathrm{~mA} / \mathrm{cm} 2$, respectively. The lower driving voltage of the new-host based device comes from the lower HOMO value and good electron transport characteristics. The current efficiency at $10000 \mathrm{~cd} / \mathrm{m} 2$ is slightly decreased from 24 to $21 \mathrm{~cd} / \mathrm{A}$. However, the power efficiency is increased from 5 to $6 \mathrm{~lm} / \mathrm{W}$.

\section{REFERENCES}

1. L. S. Hung, C. H. Chen, Materials Science and Engineering R 39 143-222 (2002).

2. L. S. Liao, K.P. Klubek and C. W. Tang, Appl. Phys. Lett. 84, 167 (2004).

3. C. Shen, I. G. Hill, A. Kahn, Adv. Mater. 11, 1523 (1999).

4. S. D. Wang, M. K. Fung, S. L. Lai, S. W. Tong, C. S. Lee, S. T. Lee, H. J. Zhang, and S. N. Bao, J. Appl. Phys. 94, 169 (2003).

5. J. Kido and T. Matsumoto, Appl. Phys. Lett. 73, 2866 (1998).

6. C. Adachi, M. A. Baldo, S. R. Forrest and M. E. Thompson, "High-efficiency organic electrophosphorescent devices with tris(2-phenylpyridine)iridium doped into electron-transporting materials," Appl. Phys. Lett. 77, 904 (2000). 